\title{
PENGARUH MODEL PEMBELAJARAN PROBLEM BASED LEARNING DENGAN PENDEKATAN SAINTIFIK TERHADAP HASIL BELAJAR SISWA PADA MATERI POKOK SUHU DAN KALOR DI KELAS X SEMESTER II SMA NEGERI 5 MEDAN T.P 2015/2016
}

\author{
Dina Juni A Sinaga dan Pintor Simamora \\ Jurusan Fisika FMIPA Universitas Negeri Medan \\ dinasinaga94@yahoo.com
}

\begin{abstract}
ABSTRAK
Penelitian ini bertujuan untuk mengetahui apakah hasil belajar siswa dengan menggunakan model problem based learning dengan pendekatan saintifik lebih baik daripada pembelajaran konvensional pada materi pokok Suhu dan Kalor kelas X semester II SMA Negeri 5 Medan T.P 2015/2016. Jenis penelitian ini adalah quasi experiment. Populasi dalam penelitian ini adalah seluruh siswa kelas X Semester genap SMA Negeri 5 Medan terdiri dari lima kelas. Sampel penelitian ini diambil dua kelas yaitu kelas X-2 (sebagai kelas eksperimen) berjumlah 31 siswa dan kelas X-1 (sebagai kelas kontrol) berjumlah 31 siswa ditentukan dengan teknik cluster random sampling. Kelas eksperimen dengan model problem based learning dan kelas kontrol dengan pembelajaran konvensional. Untuk memperoleh data yang diperlukan dalam penelitian ini digunakan tes essay dengan jumlah 8 item yang telah divalidasi sesuai dengan standar soal yang baik. Berdasarkan hasil penelitian diperoleh nilai rata-rata pretes kelas eksperimen adalah 35,22 dengan standar deviasi sebesar 12,74 dan nilai rata-rata kelas kontrol adalah 35,16 dengan standar deviasi sebesar 10,54. Setelah dilakukan uji normalitas dan uji homogenitas, data nilai pretes dari kelas eksperimen dan kontrol dinyatakan berdistribusi normal dan homogen. Melalui pengujian statistik diperoleh hasil yang signifikan bahwa kemampuan awal kedua kelas adalah setara. Kemudian diberikan perlakuan yang berbeda, kelas eksperimen dengan model problem based learning dan kelas kontrol dengan pembelajaran konvensional. Data postes yang diperoleh yaitu hasil rata-rata kelas eksperimen 72,87 dengan standar deviasi 10,62 dan kelas kontrol 68,38 dengan standar deviasi 10,48. Melalui pengujian statistik menggunakan uji-t satu pihak dapat diperoleh peningkatan hasil belajar sebesar 6,64\%, maka dapat disimpulkan bahwa menggunakan model problem based learning dengan pendekatan saintifik mempunyai pengaruh yang signifikan terhadap hasil belajar Siswa pada materi pokok Suhu dan Kalor di kelas X Semester II SMA Negeri 5 Medan T.P 2015/2016.
\end{abstract}

Kata Kunci: Model problem based learning, pembelajaran konvensional, hasil belajar siswa. 


\section{PENDAHULUAN}

\section{Pendidikan merupakan sarana} penting untuk meningkatkan kualitas sumber daya manusia dalam menjamin kelangsungan pembangunan suatu bangsa. Tanpa adanya pendidikan seseorang akan sulit untuk menyesuaikan diri dengan lingkungan dan tidak dapat berfungsi maksimal dalam lingkungan berbangsa dan bernegara. Salah satu masalah yang dihadapi dunia pendidikan kita adalah masalah lemahnya proses pembelajaran. Dalam proses pembelajaran, anak kurang didorong untuk mengembangkan kemampuan berpikir. Proses pembelajaran di dalam kelas diarahkan kepada kemampuan anak untuk menghafal informasi; otak anak dipaksa untuk mengingat dan menimbun berbagai informasi tanpa dituntut untuk memahami informasi dan diingatnya itu untuk menghubungkannya dengan kehidupan sehari-hari (Sanjaya, 2011: 1).

Menurut angket yang disebarkan pada siswa SMA Negeri 5 Medan diperoleh $62,5 \%$ menganggap bahwa pelajaran fisika itu sulit. Hal ini dapat terjadi karena dalam pembelajaran masih berpusat pada guru dan menggunakan metode ceramah. Dapat dibuktikan dengan hasil wawancara guru fisika tentang cara guru fisika mengajar di kelas sebanyak $77 \%$ cenderung berpusat pada guru ditandai dengan metode ceramah dan penugasan. Berhubungan dengan masalah tersebut, maka dipilihlah model pembelajaran problem based learning. Model problem based learning (PBL) diharapkan dapat mengatasi permasalahan yang diberikan guna untuk meningkatkan rasa ingin tahu peserta didik pada pembelajaran (Arends, 2008). Masalah diberikan kepada peserta didik, sebelum peserta didik mempelajari konsep atau materi yang berkenaan dengan masalah yang harus dipecahkan.

Model pembelajaran yang dirancang yaitu model problem based learning. Model pembelajaran pada kurikulum 2013 yang termasuk adalah problem based learning yang merupakan suatu model pembelajaran yang menantang peserta didik untuk "belajar", bekerja secara berkelompok untuk mencari solusi dari permasalahan (Daryanto, 2014: 29). Masalah yang diberikan ini digunakan untuk mengikat peserta didik pada rasa ingin tahu pada pembelajaran yang dimaksud. Masalah diberikan kepada peserta didik, sebelum peserta didik mempelajari konsep atau materi yang berkenaan dengan masalah yang harus dipecahkan. Pembelajaran pada kurikulum 2013 menggunakan pendekatan saintifik atau pendekatan berbasis proses keilmuan. Pendekatan saintifik terdiri dari mengamati, menanya, mengumpulkan informasi, mengasosiasi (mencipta) dan mengkomunikasikan.

Pendekatan saintifik adalah proses pembelajaran yang dirancang sedemikian rupa agar peserta didik secara aktif mengkonstruksi konsep, hukum atau prinsip melalui tahapan-tahapan mengamati (untuk mengidentifikasikan atau menemukan masalah), merumuskan masalah, mengajukan atau merumuskan hipotesis, mengumpulkan data dengan berbagai teknik, menganalisis data, menarik kesimpulan dan mengkomunikasikan konsep, hukum atau prinsip yang "ditemukan" (Daryanto, 2014).

Pembelajaran problem based learning dengan pendekatan saintifik membuat siswa lebih aktif dan tidak cepat bosan pada saat belajar fisika. Materi suhu dan kalor merupakan materi yang bersifat hitungan dan pemahaman sehingga pendekatan saintifik dapat digunakan sebagai salah satu pemecahan masalah pada pembelajaran suhu dan kalor. Dengan pendekatan saintifik ini, siswa dapat saling membantu dalam kelompoknya dalam menguasai konsep pada materi tersebut. Di sisi lain, pendekatan saintifik ini merupakan model pembelajaran Problem Based Learning yang kegiatan 
kelompoknya lebih mudah dikendalikan dan diawasi.

Penerapan model problem based learning ini sudah pernah diteliti oleh beberapa peneliti sebelumnya seperti Novriyanti (2014) dengan hasil penelitian menunjukan bahwa ada pengaruh penerapan model pembelajaran Problem based learning dengan pendekatan saintifik terhadap peningkatan hasil belajar siswa SMA pada materi Suhu dan Kalor. Selain itu dapat pula disimpulkan bahwa penerapan model problem based learning dengan pendekatan saintifik mengalami peningkatan secara signifikan dengan katagori tinggi dan mendapatkan respon yang sangat baik dari siswa. Namun selama penelitian dilakukan agar proses pembelajaran menjadi lebih baik maka siswa sebaiknya selalu diingatkan dengan batas waktu yang diberikan agar pembelajaran berjalan dengan lancar.

Berdasarkan uraian di atas, maka tujuan penelitian ini adalah untuk mengetahui bagaimana hasil belajar siswa pada materi pokok suhu dan kalor dengan menerapkan model pembelajaran berbasis masalah.

\section{METODE PENELITIAN}

Penelitian dilaksanakan di SMA Negeri 5 Medan beralamat di Jl.Pelajar Timur No.17 dengan waktu pelaksanaan semester II T.P 2015/2016. Populasi dalam penelitian adalah seluruh siswa kelas $\mathrm{X}$ SMA Ngeri 5 Medan yang terdiri dari 5 kelas paralel berjumlah 155 orang pada T.P 2015/2016.

Sampel dalam penelitian terdiri dari dua kelas yaitu kelas kontrol dan kelas eksperimen yang diambil dengan teknik cruster random sampling. Satu kelas dijadikan sebagai kelas eksperimen yaitu kelas X-2 yang diajarkan dengan model pembelajaran problem based learning dan satu kelas lagi dijadikan sebagai kelas control yaitu kelas X-1 yang diajarkan dengan model pembelajaran langsung. Jenis penelitian ini adalah penelitian quasi eksperimen. Desain dalam penelitian ini menggunakan two group pretest - postest design seperti ditunjukkan pada Tabel 1.

Tabel 1. Tabel Desain Penelitian (Two Group PretesPostes Design)

\begin{tabular}{|l|c|c|c|}
\hline Kelas & Pretes & Perlakuan & Postes \\
\hline Eksperimen & $\mathrm{T}_{1}$ & $\mathrm{P}$ & $\mathrm{T}_{2}$ \\
\hline Kontrol & $\mathrm{T}_{1}$ & $\mathrm{Q}$ & $\mathrm{T}_{2}$ \\
\hline
\end{tabular}

Keterangan :

$\mathrm{T}_{1}=$ Pemberian pretes; $\mathrm{T}_{2}=$ Pemberian postes; $\mathrm{P}=$ Perlakuan dengan model pembelajaran Problem Based Learning; Q $=$ Perlakuan dengan model pembelajaran langsung.

\section{HASIL DAN PEMBAHASAN}

Pada awal penelitian, kedua kelas diberikan tes uji kemampuan awal (pretest) yang bertujuan untuk mengetahui apakah kemampuan awal siswa pada kedua kelas sama atau tidak. Berdasarkan data hasil penelitian pada lampiran diperoleh nilai rata-rata pretest siswa pada kelas eksperimen sebelum diberi perlakuan dengan menggunakan model pembelajaran problem based learning sebesar 35,22 dengan standar deviasi 12,74 dan di kelas control diperoleh nilai rata-rata pretest siswa sebesar 35,16 dengan standar deviasi 10,54 .

Untuk melihat secara rinci hasil pretes kedua kelas dapat dilihat pada Gambar 1.

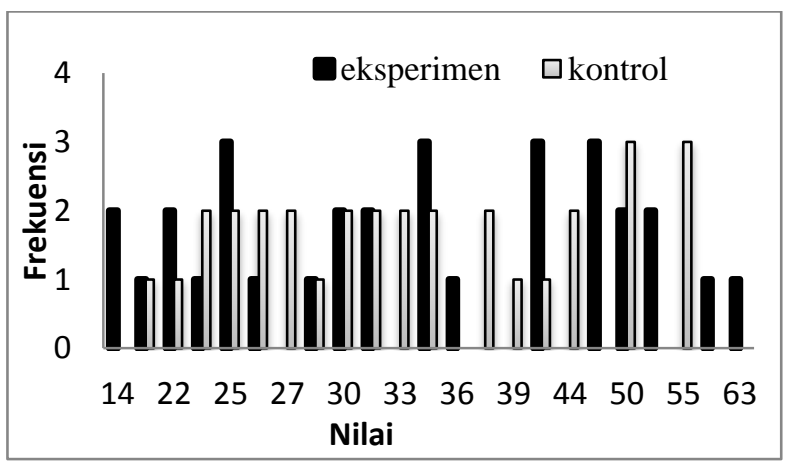

Gambar 1. Hubungan Pretest Kelas Eksperimen dan Kelas Kontrol 
Gambar 1 menunjukkan bahwa nilai pretes pada kelas eksperimen dan kelas kontrol tidak jauh berbeda, artinya kedua kelas mempunyai kemampuan awal yang hampir sama dan perolehan nilai kedua kelas merata.

Sebelum dilakukan uji hipotesis terlebih dahulu dilakukan uji prasyarat data yaitu uji normalitas menggunakan uji Lilliefors. Hasil uji normalitas yang diperoleh adalah Kelas Eksperimen Lhitung $=0,1544, \mathrm{~L}_{\text {tabel }}=0,1591$. Untuk kelas kontrol $\mathrm{L}_{\text {hitung }}=0,1276, \mathrm{~L}_{\text {tabel }}=0,1591$. Kesimpulannya kedua kelas berdistribusi normal.

Pengujian homogenitas dilakukan untuk mengetahui apakah kelas sampel berasal dari populasi yang homogen atau tidak, artinya apakah sampel yang dipakai dalam penelitian ini dapat mewakili seluruh populasi yang ada.

Pengujian homogenitas data dilakukan dengan uji F. Hasil uji homogenitas data yang diperoleh adalah $F_{\text {hitung }}<\mathrm{F}_{\text {tabel }}=1,46<1,84$. Nilai $F_{\text {hitung }}<\mathrm{F}$ tabel yang berarti bahwa sampel yang digunakan dalam penelitian ini dinyatakan homogeny atau dapat mewakili seluruh populasi yang ada.

Setelah kedua kelas diberikan perlakuan yang berbeda, kedua kelas selanjutnya diberikan posttest dengan soal yang sama seperti soal pretest yang bertujuan untuk mengetahui hasil belajar siswa. Hasil yang diperoleh adalah Berdasarkan data hasil penelitian pada lampiran diperoleh nilai rata-rata posttest siswa pada kelas eksperimen setelah diberi perlakuan dengan menggunakan model pembelajaran problem based learning sebesar 72,87 dengan standar deviasi 10,62 dan di kelas kontrol diperoleh nilai ratarata posttest siswa sebesar 68,38 dengan standar deviasi 10,48.

Untuk melihat secara rinci hasil protes kedua kelas dapat dilihat pada Gambar 2.

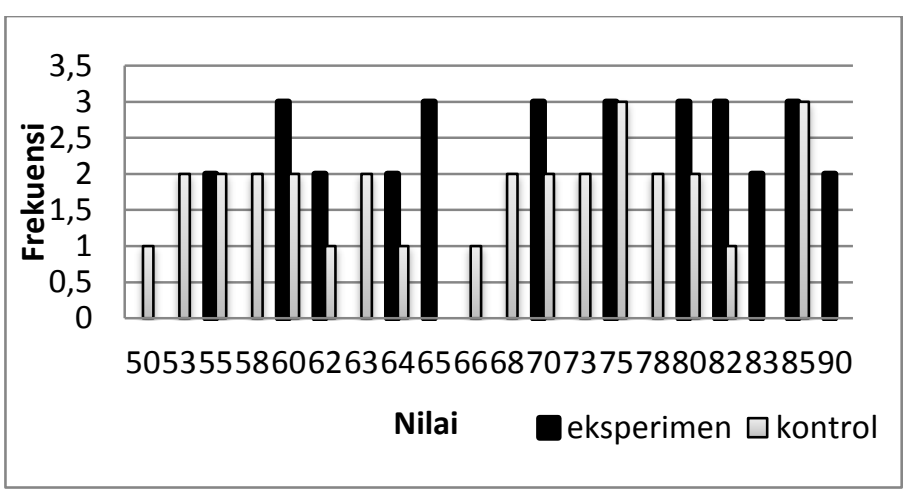

Gambar 2. Perbandingan Nilai Postest Kelas Eksperimen dan Kelas Kontrol

Gambar 2 menunjukkan bahwa pada kelas eksperimen, nilai yang dicapai oleh siswa lebih merata dibandingkan pada kelas kontrol. Hal ini menunjukkan bahwa penerapan model pembelajaran problem based learning baik untuk dilakukan.

Berdasarkan hasil uji hipotesis diperoleh $t_{\text {hitung }}>t_{\text {tabel }}=1,7364>1,67$. Dalam hal ini dapat disimpulkan bahwa hasil belajar siswa pada kelas eksperimen lebih besar dari hasil belajar kelas kontrol, berarti ada pengaruh yang signifikan akibat model pembelajaran Problem Based Learning terhadap hasil belajar pada materi pokok Suhu dan Kalor di kelas X SMA Negeri 5 Medan T.P 2015/2016.

\section{KESIMPULAN}

Kesimpulan penelitian ini didasarkan pada temuan-temuan dari datadata dan pembahasan hasil penelitian, sistematika sajiannya dilakukan dengan memperhatikan tujuan penelitian yang telah dirumuskan. Adapun kesimpulan yang diperoleh antara lain :

1. Hasil belajar siswa yang diberi pembelajaran dengan model Problem Based Learning pada materi pokok suhu dan kalor di kelas X SMAN 5 Medan T.P 2015/2016 sebelum diberikan perlakuan rata-rata pretes siswa sebesar 35,22 dan setelah diberikan 
perlakuan rata-rata postest siswa sebesar 72,87 .

2. Hasil belajar siswa yang diberi pembelajaran dengan konvensional pada materi pokok suhu dan kalor di kelas X SMAN 5 Medan T.P 2015/2016 sebelum diberikan perlakuan rata-rata pretes siswa sebesar 35,16 dan setelah diberikan perlakuan rata-rata postes siswa sebesar 68,38.

3. Ada pengaruh model Problem Based Learning dengan pendekatan saintifik terhadap hasil belajar siswa pada materi pokok suhu dan kalor di kelas X SMAN 5 Medan T.P 2015/2016 sebesar 6,64\%.

\section{DAFTAR PUSTAKA}

Arends, R. I., (2008), Learning to Teach Edisi Ketujuh, Pustaka Belajar, Yogyakarta.
Arikunto. (2012). Dasar-dasar Evaluasi Pendidikan. Bumi Aksara. Jakarta

Daryanto, (2014), Pendekatan Pembelajaran Saintifik Kurikulum 2013, Gava Media, Yogyakarta.

Novriyanti, A., dan Derlina, (2014), Pengaruh model pembelajaran berbasis masalah terhadap hasil belajar siswa pada materi pokok suhu dan kalor di kelas $X$ Semester II SMA Negeri DeliTua, Jurnal Inpafi 02 : 89-96.

Sanjaya, W., (2011), Strategi Pembelajaran Berorientasi Standar Proses Pendidikan, Kencana Prenada Media Group, Jakarta. 